\title{
Zinc and copper in multiple sclerosis
}

\author{
R PALM, ${ }^{*}$ G HALLMANS $\dagger$ \\ From the Biophysical Laboratory, and the Departments of Neurology* and Pathology, $\dagger$ University of Umea, \\ Umea, Sweden
}

SUMMARY The serum concentrations of zinc and copper were measured in 50 patients with multiple sclerosis. Lower serum zinc levels were found compared to age- and sex-matched controls. In younger patients low serum copper concentrations were noted. Zinc concentrations in CSF were unchanged. The possibility that malabsorption of the metals causes the low serum concentrations is discussed.

In the search for the aetiology and pathogenesis of multiple sclerosis some interest has been expressed in the role of the trace elements zinc $(\mathrm{Zn})$ and copper $(\mathrm{Cu})$. Epidemiological data has shown a low prevalence of the disease in seacoast towns, ${ }^{1}$ where the intake of seafood, rich in $\mathrm{Zn}$, is high. ${ }^{2} \mathrm{Zinc}$ and copper deficiency in some animal species may lead to hypomyelinisation. ${ }^{3-9}$ Conflicting reports of serum and plasma concentrations of $\mathrm{Zn}$ and $\mathrm{Cu}$ in multiple sclerosis have been published. Plasma $\mathrm{Zn}$ has been reported to be increased in 50 patients. ${ }^{10}$ Decreased plasma $\mathrm{Zn}$ levels were reported by Wong et al ${ }^{11}$ in 25 patients, 14 of whom had clinically definite multiple sclerosis. Serum $\mathrm{Cu}$ has been reported to be decreased, ${ }^{12}$ or unchanged. ${ }^{13-16}$ In addition, serum albumin, which binds about $80 \%$ of the $\mathrm{Zn}$ in serum, ${ }^{17}$ has been said to be decreased ${ }^{18-20}$ or unchanged, ${ }^{10}$ while the serum $\alpha_{2}$-macroglobulin, which binds about $20 \%$ of the $\mathrm{Zn}$ in serum, has been said to be depressed. ${ }^{10}{ }^{18-20}$ Transient elevations of several acute-phase reactants in serum, for example $\mathrm{C}_{3}$-pro-activator, C-reactive protein, orosomucoid and $\operatorname{IgM}$, have been found during exacerbations of the disease. ${ }^{21}$

The aim of the present study was to correlate changes in the serum concentrations of $\mathrm{Zn}, \mathrm{Cu}$ and albumin in multiple sclerosis patients with the age of the patients, the phase and duration of the disease, and the degree of disability. In addition the concentrations of CSF $\mathrm{Zn}$ were determined, and their relationship to the CSF proteins studied.

Address for reprint requests: Dr R Palm, Department of Neurology, University Hospital, S-901 85 Umeå, Sweden.

Received 13 February 1982

Accepted 9 April 1982

\section{Patients and methods}

\section{Patients}

Serum was collected from 50 patients with clinically definite multiple sclerosis according to the criteria of McDonald and Halliday. ${ }^{22}$ Patients from a neurological ward and a rehabilitation centre, as well as outpatients, were included in the study over three years. Twenty-one were males, median age 34 years (range 22-68), and 29 females, median age 39 years (range 23-76). The median age for the first symptoms of the disease was 26 years (range 14-52) for the males and 29 (range 15-41) for the females. None of the patients were on ACTH, corticosteroid, oestrogen, oral contraceptive or phenytoin therapy, all of which may alter the serum concentrations of $\mathrm{Zn}$ and $\mathrm{Cu}$. Blood $\mathrm{Hb}$ was more than $115 \mathrm{~g} / \mathrm{l}$ and ESR less than 25 $\mathrm{mm} / \mathrm{h}$ in all patients. None of the women was pregnant. No clinical or laboratory signs of acute or chronic infection, malnutrition, liver disease or pressure sores were observed. From 29 of the patients, 11 males and 18 females, CSF samples also were obtained.

Age and sex matched control serum samples were selected from a pool of 75 healthy volunteers from the same geographical area as the patients. They were taking no drugs, including oral contraceptives, and they had no clinical or laboratory signs of infection, anaemia or liver disease. None of the women was pregnant. Age- and sexmatched controls for the patients who provided CSF samples were taken from a pool of $52 \mathrm{CSF}$ samples assumed to be normal. Eighteen came from healthy volunteers ${ }^{23}$ and the remainder from patients with psychoneurosis, tension headache and other pain syndromes in whom neurological examination failed to define an organic CNS lesion. All had macroscopically clear CSF with a leucocyte count of less than $5 / \mu 1$, and a CSF protein concentration of less than $500 \mathrm{mg} / 1$.

\section{Clinical parameters}

The stage of disease at the time of sampling was described as (a) acute exacerbation if the symptoms had started within the previous ten days, or (b) remission or steady state if new symptoms were older than ten days, had com- 
pletely or partially disappeared or if the disease was in "steady state", or as (c) slowly progressive disease. Duration, disability levels and degree of malignancy of disease were registered and scored according to Johnson et al. ${ }^{24}$ The duration of the disease was scored as 5 when it was 1-3 years, 4 when it was 4-6 years, 3 when it was 7-9 years, 2 when it was $10-15$ years, and 1 when it was $>15$ years. The disability level was scored as mild, moderate or severe: mild (score 2 ): the residual symptoms were slight and the patient could work in his regular occupation; moderate (score 3 ): the patient could perform activities of daily living but not work regularly; severe (score 4): the patient was severely incapacitated. The degree of malignancy of the disease, the amount of disability of the disease in relation to the duration, was estimated by multiplying the scores for duration and disability level. A high score meant a severe degree of malignancy.

\section{Serum and CSF sampling and analysis}

All samples were collected at 08.00-09.00 after an overnight fast. The blood samples were taken from an antecubital vein after minimal stasis, into acid washed glass tubes. The vacutainer was not used, to avoid zinc contamination from the rubber stopper. When additional blood samples were taken, the sample for $\mathrm{Zn}$ and $\mathrm{Cu}$ analysis was taken in the first tube. The blood was allowed to clot for about two hours, centrifuged at $5000 \mathrm{r} / \mathrm{min}$ for 15 minutes. The serum was transferred to acid washed plastic tubes with Pasteur pipettes and frozen at $-20^{\circ} \mathrm{C}$ until analysis. All samples were analysed as a batch. Serum $\mathrm{Zn}$ and $\mathrm{Cu}$ were analysed by flame atomic absorption spectrophotometry in a Varian AA-6DB. The samples were diluted eleven times with $0.1 \mathrm{~mol} / \mathrm{HCl}$, and $\mathrm{Zn}$ and $\mathrm{Cu}$ determined at 213.9 and $324.7 \mathrm{~nm}$ respectively. ${ }^{25}$

CSF samples were obtained by lumbar puncture ith the patient in the lateral recumbent position. Samples after approximately the 15 th ril were used for the analysis of $\mathrm{Zn}$, CSF protein and CSF albumin. CSF samples which were cloudy or coloured were rejected. CSF Zn concentrations were determined by the flame atomic absorption spectrophotometry and using a pulse nebuliser technique. The puncture technique, sample handling and analytical procedures were described in a previous report. ${ }^{23} \mathrm{CSF}$ protein was determined according to Lowry $e t a^{26}$ with tyrosine as the standard. Albumin in serum and CSF was analysed by electroimmunoassay according to Laurell. ${ }^{27}$

\section{Statistics}

The differences between group means for different variables were tested using Student's $t$ test. The test was modified if the variances were significantly different $(p<0.01$; $F$ test). Product moment correlation coefficients $(r)$ were calculated for selected variables and tested using Student's $t$ test. $\mathrm{p}<0.05^{*}, \mathrm{p}<0.01 \dagger$, and $\mathrm{p}<0.001 \ddagger$ were chosen as levels of statistical significance.

\section{Results}

\section{SERUM CONCENTRATIONS (table 1)}

Lower serum $\mathrm{Zn}$ concentrations were found in the multiple sclerosis patients compared with the controls. Also the serum $\mathrm{Cu}$ concentrations were slightly lower in the patients but the difference was not significant. The patients had more variability in their serum $\mathrm{Cu}$ levels than the controls. Higher $\mathrm{Zn}$ and lower $\mathrm{Cu}$ levels were found in the serum of control males compared with those of females $(\mathrm{p}=$ 0.002 and 0.008 respectively). A slight similar difference of $\mathrm{Zn}$ and $\mathrm{Cu}$ concentrations in serum was also found in the patients; however, it was not statistically significant. The serum albumin concentration did not differ between either the patients and the controls, or between the sexes.

\section{RELATION TO AGE (table 2, figs 1 and 2)}

For patients younger than 45 years, lower $\mathrm{Zn}$ and $\mathrm{Cu}$ serum levels were found in the males and lower $\mathrm{Cu}$ concentrations in the females compared to the controls. After 45 years no significant changes of serum $\mathrm{Zn}$ or $\mathrm{Cu}$ concentrations were noted. The serum albumin concentrations did not differ from the controls in any of the age groups.

When serum $\mathrm{Zn}$ and $\mathrm{Cu}$ concentrations were correlated with age a negative correlation was found between serum $\mathrm{Zn}$ and age in the control males, but not in the multiple sclerosis patients (fig 1). For the multiple sclerosis males a positive correlation was found between serum $\mathrm{Cu}$ and age, but not in the controls. For the females no correlations were found between age and the serum concentrations of $\mathrm{Zn}$ and $\mathrm{Cu}$ (fig 2).

\section{CLINICAL PARAMETERS}

Stage of disease (table 3) Lower serum $\mathrm{Zn}$ concentrations were found in males with slowly progressive disease, and slightly lower serum albumin levels were seen in males in remission or steady state.

Duration and disability (tables 4 and 5) Males with short duration and mild residual symptoms had low

Table 1 Serum concentrations of $\mathrm{Zn}, \mathrm{Cu}$ and albumin in patients with multiple sclerosis (MS) and age and sex matched controls. The results are given as the mean $\pm S D$. Significant differences between patients and controls are indicated

\begin{tabular}{|c|c|c|c|c|}
\hline & \multicolumn{2}{|c|}{ Males $(n=21)$} & \multicolumn{2}{|c|}{ Females $(n=29)$} \\
\hline & $\overline{M S}$ & Controls & $M S$ & Controls \\
\hline $\begin{array}{l}\mathrm{Zn}(\mu \mathrm{mol} / \mathrm{h}) \\
\mathrm{Cu}(\mu \mathrm{mol} / /) \\
\text { Albumin }(\mathrm{g} / \mathrm{l})\end{array}$ & $\begin{array}{l}13 \cdot 0 \pm 1 \cdot 9 \ddagger \\
14 \cdot 7 \pm 3 \cdot 7 \\
42 \pm 3\end{array}$ & $\begin{array}{l}14.8 \pm 1.6 \\
15.3 \pm 1.6 \\
43 \pm 4\end{array}$ & $\begin{array}{l}12 \cdot 1 \pm 2 \cdot 1^{*} \\
15 \cdot 7 \pm 3 \cdot 3 \\
41 \pm 4\end{array}$ & $\begin{array}{l}13 \cdot 2 \pm 1 \cdot 6 \\
16 \cdot 8 \pm 2 \cdot 1 \\
41 \pm 3\end{array}$ \\
\hline
\end{tabular}


Table 2 Serum concentrations of $\mathrm{Zn}, \mathrm{Cu}$ and albumin in patients with multiple sclerosis (MS) and controls in two different age groups. All results are given as the mean $\pm S D$. Significant differences between patients and controls are indicated

\begin{tabular}{|c|c|c|c|c|}
\hline & \multicolumn{4}{|l|}{ Males } \\
\hline & \multicolumn{2}{|c|}{$<45$ years $(n=14)$} & \multicolumn{2}{|c|}{$\geqslant 45$ years $(n=7)$} \\
\hline & $M S$ & Controls & $M S$ & Controls \\
\hline \multirow[t]{4}{*}{$\begin{array}{l}\text { Mean age (years) } \\
\text { Zn }(\mu \mathrm{mol} / /) \\
\text { Cu }(\mu \mathrm{mol} / /) \\
\text { Albumin }(\mathrm{g} / \mathrm{l})\end{array}$} & $\begin{array}{l}33 \pm 6 \\
13 \cdot 5 \pm 2 \cdot 1 \dagger \\
13 \cdot 8 \pm 2 \cdot 3 \dagger \\
43 \pm 4\end{array}$ & $\begin{array}{ll}33 & \pm 6 \\
15 \cdot 4 & \pm 1 \cdot 3 \\
15 \cdot 8 & \pm 1 \cdot 4 \\
43 \quad \pm 4\end{array}$ & $\begin{array}{l}53 \pm 9 \\
12 \cdot 1 \pm 1 \cdot 2 \\
16 \cdot 5 \pm 5 \cdot 3 \\
41 \pm 2\end{array}$ & $\begin{array}{l}52 \pm 7 \\
13 \cdot 5 \pm 1 \cdot 2 \\
14 \cdot 2 \pm 1 \cdot 7 \\
45 \pm 4\end{array}$ \\
\hline & \multicolumn{4}{|l|}{ Females } \\
\hline & \multicolumn{2}{|c|}{$<45$ years $(n=19)$} & \multicolumn{2}{|c|}{$\geqslant 45$ years $(n=10)$} \\
\hline & $M S$ & Controls & $M S$ & Controls \\
\hline $\begin{array}{l}\text { Mean age (years) } \\
\mathrm{Zn}(\mu \mathrm{mol} / /) \\
\mathrm{Cu}(\mu \mathrm{mol} / /) \\
\text { Albumin }(\mathrm{g} / \mathrm{l})\end{array}$ & $\begin{array}{l}31 \pm 6 \\
12 \cdot 6 \pm 1 \cdot 9 \\
15 \cdot 1 \pm 3 \cdot 2^{*} \\
41 \pm 4\end{array}$ & $\begin{array}{ll}31 & \pm 6 \\
13 \cdot 4 & \pm 1 \cdot 4 \\
16 \cdot 9 & \pm 2 \cdot 1 \\
40 & \pm 4\end{array}$ & $\begin{array}{l}55 \pm 9 \\
11 \cdot 0 \pm 2 \cdot 3 \\
16 \cdot 7 \pm 3 \cdot 4 \\
40 \pm 4\end{array}$ & $\begin{array}{l}54 \pm 7 \\
12 \cdot 9 \pm 1 \cdot 9 \\
16 \cdot 6 \pm 2 \cdot 3 \\
41 \pm 3\end{array}$ \\
\hline
\end{tabular}

* $=p<0.05, \dagger=p<0.01, \ddagger=p<0.001$
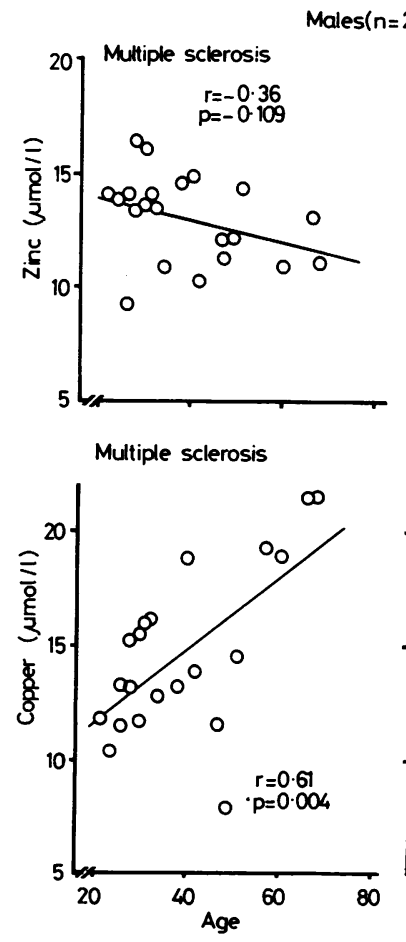

Controls

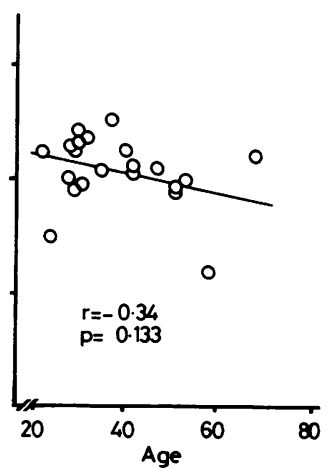

Fig 1 Serum concentrations of zinc and copper in relation to age in males with multiple sclerosis and controls $(n=21)$.
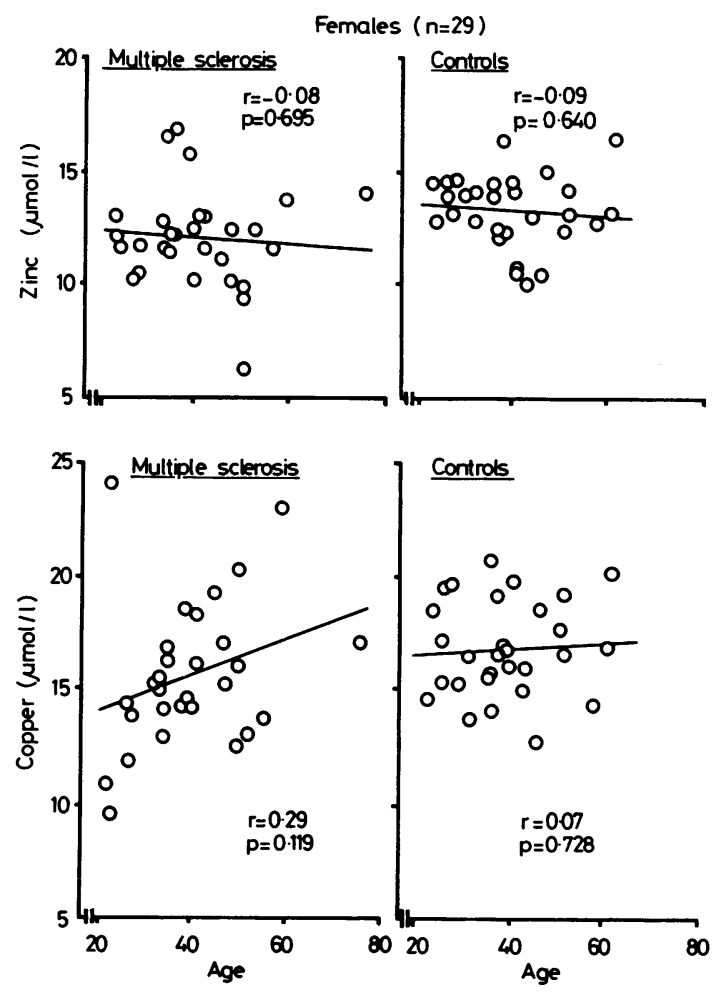

Fig 2 Serum concentrations of zinc and copper in relation to age in females with multiple sclerosis and controls $(n=$ 29). 
Table 3 Serum concentrations of $\mathrm{Zn}, \mathrm{Cu}$ and albumin in patients with multiple sclerosis (MS) and controls in relation to the stage of the disease. $\mathrm{Zn}$ and $\mathrm{Cu}$ are expressed in umolll, albumin in $\mathrm{g} / \mathrm{l}$. The results are expressed as the mean $\pm S D$. Significant differences between patients and controls are indicated

\begin{tabular}{|c|c|c|c|c|c|}
\hline & & \multicolumn{2}{|l|}{ Males } & \multicolumn{2}{|l|}{ Females } \\
\hline & & $M S$ & Controls & $M S$ & Controls \\
\hline Exacerbation & $\begin{array}{l}\text { Mean age } \\
\text { Zn } \\
\text { Cu } \\
\text { Albumin }\end{array}$ & $\begin{array}{l}28(n=1) \\
16 \cdot 4 \\
13 \cdot 1 \\
44\end{array}$ & $\begin{array}{l}28 \\
14 \cdot 4 \\
15 \cdot 0 \\
49\end{array}$ & $\begin{array}{l}38 \pm 10(n=6) \\
12 \cdot 6 \pm 2 \cdot 3 \\
14 \cdot 9 \pm 2 \cdot 7 \\
42 \pm 3\end{array}$ & $\begin{array}{l}39 \pm 11 \\
13 \cdot 2 \pm 0 \cdot 9 \\
15 \cdot 9 \pm 2 \cdot 1 \\
42 \pm 4\end{array}$ \\
\hline Remission or steady state & $\begin{array}{l}\text { Mean age } \\
\mathrm{Zn} \\
\mathrm{Cu} \\
\text { Albumin }\end{array}$ & $\begin{array}{l}36 \pm 13(n=8) \\
13.8 \pm 1.6 \\
13.7 \pm 3.9 \\
41 \pm 3^{*}\end{array}$ & $\begin{array}{l}36 \pm 12 \\
15 \cdot 1 \pm 1 \cdot 2 \\
15 \cdot 3 \pm 1 \cdot 4 \\
45 \pm 2\end{array}$ & $\begin{array}{l}41 \pm 14(n=15) \\
12 \cdot 4 \pm 2 \cdot 4 \\
16 \cdot 0 \pm 3 \cdot 5 \\
41 \pm 4\end{array}$ & $\begin{array}{l}40 \pm 12 \\
13.7 \pm 1 \cdot 6 \\
17 \cdot 0 \pm 1 \cdot 9 \\
41 \pm 3\end{array}$ \\
\hline Slowly progressive & $\begin{array}{l}\text { Mean age } \\
\mathrm{Zn} \\
\mathrm{Cu} \\
\text { Albumin }\end{array}$ & $\begin{array}{l}42 \pm 14(n=12) \\
12 \cdot 2 \pm 1 \cdot 6 \neq \\
15 \cdot 5 \pm 3 \cdot 6 \\
43 \pm 3\end{array}$ & $\begin{array}{l}42 \pm 13 \\
14 \cdot 6 \pm 1 \cdot 9 \\
15 \cdot 3 \pm 1 \cdot 9 \\
42 \pm 4\end{array}$ & $\begin{array}{l}39 \pm 10(n=8) \\
11 \cdot 0 \pm 1 \cdot 2 \\
15 \cdot 6 \pm 3 \cdot 5 \\
39 \pm 5\end{array}$ & $\begin{array}{l}39 \pm 9 \\
12 \cdot 4 \pm 1 \cdot 9 \\
17 \cdot 1 \pm 2 \cdot 6 \\
40 \pm 3\end{array}$ \\
\hline
\end{tabular}

$*=p<0.05, \dagger=p<0.01, \ddagger=p<0.001$

Table 4 Serum concentrations of $\mathrm{Zn}, \mathrm{Cu}$ and albumin in patients with multiple sclerosis (MS) and controls in relation to the duration of the disease. $\mathrm{Zn}$ and $\mathrm{Cu}$ are expressed in umolll, albumin in g/l. The results are given as the mean $\pm S D$. Significant differences between patients and controls are indicated

\begin{tabular}{|c|c|c|c|c|c|}
\hline \multirow[t]{2}{*}{ Duration } & & \multicolumn{2}{|l|}{ Males } & \multicolumn{2}{|l|}{ Females } \\
\hline & & $M S$ & Controls & $M S$ & Controls \\
\hline $1-6$ years & $\begin{array}{l}\text { Mean age } \\
\mathrm{Zn} \\
\mathrm{Cu} \\
\text { Albumin }\end{array}$ & $\begin{array}{l}30 \pm 6(n=10) \\
13 \cdot 8 \pm 2 \cdot 2 \\
13 \cdot 2 \pm 2 \cdot 4^{*} \\
42 \pm 4\end{array}$ & $\begin{array}{l}31 \pm 6 \\
15 \cdot 1 \pm 1 \cdot 3 \\
15 \cdot 7 \pm 1 \cdot 4 \\
44 \pm 3\end{array}$ & $\begin{array}{l}32 \pm 8(n=14) \\
12 \cdot 6 \pm 2 \cdot 0 \\
15 \cdot 0 \pm 3 \cdot 5 \\
42 \pm 3\end{array}$ & $\begin{array}{l}33 \pm 7 \\
13.7 \pm 1.4 \\
16.9 \pm 1 \cdot 9 \\
41 \pm 4\end{array}$ \\
\hline $7-15$ years & $\begin{array}{l}\text { Mean age } \\
\mathrm{Zn} \\
\mathrm{Cu} \\
\text { Albumin }\end{array}$ & $\begin{array}{l}46 \pm 14(n=6) \\
13 \cdot 1 \pm 0 \cdot 8^{*} \\
15 \cdot 8 \pm 4 \cdot 7 \\
42 \pm 2\end{array}$ & $\begin{array}{l}45 \pm 12 \\
15 \cdot 0 \pm 1 \cdot 4 \\
14 \cdot 4 \pm 1 \cdot 9 \\
45 \pm 4\end{array}$ & $\begin{array}{l}42 \pm 9(n=9) \\
11 \cdot 1 \pm 2 \cdot 6 \\
15 \cdot 5 \pm 2 \cdot 9 \\
41 \pm 4\end{array}$ & $\begin{array}{l}42 \pm 9 \\
12 \cdot 9 \pm 1 \cdot 2 \\
16.9 \pm 2 \cdot 6 \\
41 \pm 3\end{array}$ \\
\hline$>15$ years & $\begin{array}{l}\text { Mean age } \\
\mathrm{Zn} \\
\mathrm{Cu} \\
\text { Albumin }\end{array}$ & $\begin{array}{l}50 \pm 15(n=5) \\
11 \cdot 5 \pm 1 \cdot 4^{*} \\
16 \cdot 4 \pm 3 \cdot 9 \\
43 \pm 3\end{array}$ & $\begin{array}{l}50 \pm 12 \\
13 \cdot 8 \pm 2 \cdot 1 \\
15 \cdot 4 \pm 1 \cdot 5 \\
42 \pm 5\end{array}$ & $\begin{array}{l}53 \pm 14(n=6) \\
12 \cdot 2 \pm 1 \cdot 4 \\
17 \cdot 6 \pm 3 \cdot 1 \\
38 \pm 4\end{array}$ & $\begin{array}{l}51 \pm 11 \\
12 \cdot 8 \pm 2 \cdot 4 \\
16 \cdot 5 \pm 2 \cdot 1 \\
39 \pm 2\end{array}$ \\
\hline
\end{tabular}

$*=p<0.05$

Table 5 Serum concentrations of $\mathrm{Zn}, \mathrm{Cu}$ and albumin in patients with multiple sclerosis (MS) and controls in relation to the disability level of the disease. $Z n$ and $C u$ are expressed in umolll, albumin in $g / l$. The results are given as the mean $\pm S D$. Significant differences between patients and controls are indicated

\begin{tabular}{|c|c|c|c|c|c|}
\hline \multirow[t]{2}{*}{ Disability } & & \multicolumn{2}{|l|}{ Males } & \multicolumn{2}{|l|}{ Females } \\
\hline & & $M S$ & Controls & $M S$ & Controls \\
\hline Mild & $\begin{array}{l}\text { Mean age } \\
\text { Zn } \\
\text { Cu } \\
\text { Albumin }\end{array}$ & $\begin{array}{l}34 \pm 11(n=8) \\
13 \cdot 8 \pm 1 \cdot 7 \\
12 \cdot 1 \pm 2 \cdot 1 \dagger \\
41 \pm 3 \dagger\end{array}$ & $\begin{array}{l}35 \pm 11 \\
14 \cdot 8 \pm 1 \cdot 4 \\
15 \cdot 1 \pm 1 \cdot 3 \\
45 \pm 3\end{array}$ & $\begin{array}{l}36 \pm 10(n=15) \\
12 \cdot 4 \pm 2 \cdot 2 \\
15 \cdot 6 \pm 3 \cdot 3 \\
41 \pm 3\end{array}$ & $\begin{array}{l}36 \pm 10 \\
13 \cdot 3 \pm 1 \cdot 6 \\
16 \cdot 4 \pm 2 \cdot 2 \\
41 \pm 4\end{array}$ \\
\hline Moderate & $\begin{array}{l}\text { Mean age } \\
\text { Zn } \\
\text { Cu } \\
\text { Albumin }\end{array}$ & $\begin{array}{l}37 \pm 11(n=8) \\
13 \cdot 0 \pm 2 \cdot 2^{*} \\
16 \cdot 0 \pm 3 \cdot 1 \\
44 \pm 4\end{array}$ & $\begin{array}{l}38 \pm 9 \\
15 \cdot 2 \pm 1 \cdot 4 \\
16 \cdot 3 \pm 1 \cdot 1 \\
43 \pm 5\end{array}$ & $\begin{array}{l}47 \pm 12(n=10) \\
11 \cdot 7 \pm 2 \cdot 5 \\
15 \cdot 5 \pm 2 \cdot 2 \\
42 \pm 4\end{array}$ & $\begin{array}{l}45 \pm 9 \\
13 \cdot 0 \pm 1 \cdot 9 \\
17 \cdot 1 \pm 2 \cdot 3 \\
41 \pm 3\end{array}$ \\
\hline Severe & $\begin{array}{l}\text { Mean age } \\
\mathrm{Zn} \\
\mathrm{Cu} \\
\text { Albumin }\end{array}$ & $\begin{array}{l}50 \pm 17(n=5) \\
11 \cdot 8 \pm 1 \cdot 3^{*} \\
16 \cdot 8 \pm 4 \cdot 6 \\
42 \pm 3\end{array}$ & $\begin{array}{l}50 \pm 15 \\
14 \cdot 0 \pm 2 \cdot 0 \\
14 \cdot 0 \pm 2 \cdot 0 \\
42 \pm 3\end{array}$ & $\begin{array}{l}37 \pm 16(n=4) \\
11 \cdot 8 \pm 1 \cdot 4 \\
16 \cdot 2 \pm 5 \cdot 8 \\
36 \pm 2 *\end{array}$ & $\begin{array}{l}38 \pm 15 \\
13.6 \pm 0.7 \\
17 \cdot 5 \pm 1 \cdot 3 \\
39 \pm 1\end{array}$ \\
\hline
\end{tabular}

$*=\mathrm{p}<0.05, \dagger=\mathrm{p}<0.01$ 
Table 6 Serum concentrations of $\mathrm{Zn}, \mathrm{Cu}$ and albumin in patients with multiple sclerosis (MS) and controls in relation to the degree of malignancy (duration score $\times$ disability level) $\mathrm{Zn}$ and $\mathrm{Cu}$ are expressed in $\mu m o l / l$, albumin in $\mathrm{g} / \mathrm{l}$. The results are given as the mean $\pm S D$. Significant differences between patients and controls are indicated

\begin{tabular}{|c|c|c|c|c|c|}
\hline \multirow[t]{2}{*}{ Score } & & \multicolumn{2}{|l|}{ Males } & \multicolumn{2}{|l|}{ Females } \\
\hline & & $M S$ & Controls & $M S$ & Controls \\
\hline $1-8$ & $\begin{array}{l}\text { Mean age } \\
\text { Zn } \\
\text { Cu } \\
\text { Albumin }\end{array}$ & $\begin{array}{l}44 \pm 15(n=13) \\
12 \cdot 4 \pm 1 \cdot 4 \ddagger \\
15 \cdot 2 \pm 4 \cdot 2 \\
41 \pm 3\end{array}$ & $\begin{array}{l}44 \pm 13 \\
14 \cdot 3 \pm 1 \cdot 6 \\
14 \cdot 9 \pm 1 \cdot 8 \\
43 \pm 4\end{array}$ & $\begin{array}{l}47 \pm 12(n=15) \\
11 \cdot 6 \pm 2 \cdot 3 \\
16 \cdot 1 \pm 2 \cdot 9 \\
40 \pm 4\end{array}$ & $\begin{array}{l}46 \pm 10 \\
13 \cdot 0 \pm 1 \cdot 8 \\
17 \cdot 1 \pm 2 \cdot 2 \\
40 \pm 3\end{array}$ \\
\hline $9-20$ & $\begin{array}{l}\text { Mean age } \\
\text { Zn } \\
\text { Cu } \\
\text { Albumin }\end{array}$ & $\begin{array}{l}30 \pm 6(n=8) \\
14 \cdot 0 \pm 2 \cdot 2 \\
13 \cdot 9 \pm 2 \cdot 5 \\
44 \pm 4\end{array}$ & $\begin{array}{l}31 \pm 7 \\
15 \cdot 5 \pm 1 \cdot 3 \\
15 \cdot 9 \pm 1 \cdot 1 \\
43 \pm 4\end{array}$ & $\begin{array}{l}32 \pm 7(n=14) \\
12 \cdot 6 \pm 2 \cdot 0 \\
15 \cdot 2 \pm 3 \cdot 7 \\
42 \pm 3\end{array}$ & $\begin{array}{l}32 \pm 7 \\
13 \cdot 5 \pm 1 \cdot 4 \\
16 \cdot 4 \pm 2 \cdot 0 \\
41 \pm 4\end{array}$ \\
\hline
\end{tabular}

$\ddagger=\mathrm{p}<0.001$

Table 7 CSF concentrations of $\mathrm{Zn}$, protein, albumin and the ratio CSF/serum albumin $\times 10^{3}$ in patients with multiple sclerosis (MS) and controls. All results are given as the mean $\pm S D$. Significant differences between patients and controls are indicated

\begin{tabular}{|c|c|c|}
\hline & \multicolumn{2}{|l|}{ Males $(n=11)$} \\
\hline & $M S$ patients & Controls \\
\hline \multirow[t]{3}{*}{$\begin{array}{l}\text { Mean age } \\
\text { CSF Zn }(\mu \mathrm{mol} / \mathrm{l}) \\
\text { CSF protein }(\mathrm{mg} / 1) \\
\text { CSF albumin }(\mathrm{mg} /) \\
\text { CSF } / \text { serum albumin } \times 10^{3}\end{array}$} & $\begin{array}{c}39 \pm 14 \\
0 \cdot 14 \pm 0.03 \\
345 \pm 87 \\
166 \pm 53 \\
3.9 \pm 1 \cdot 2^{*}\end{array}$ & $\begin{array}{c}39 \pm 10 \\
0 \cdot 17 \pm 0.05 \\
376 \pm 64 \\
206 \pm 50 \\
5 \cdot 1 \pm 1 \cdot 3\end{array}$ \\
\hline & \multicolumn{2}{|c|}{ Females $(n=18)$} \\
\hline & $M S$ patients & Controls \\
\hline $\begin{array}{l}\text { Mean age } \\
\text { CSF Zn }(\mu \mathrm{mol} / 1) \\
\text { CSF protein }(\mathrm{mg} /) \\
\text { CSF albumin }(\mathrm{mg} / \mathrm{l}) \\
\text { CSF/serum albumin } \times 10^{3}\end{array}$ & $\begin{array}{c}37 \pm 11 \\
0 \cdot 15 \pm 0.06 \\
370 \pm 97 \\
185 \pm 72 \\
4.8 \pm 1.8\end{array}$ & $\begin{array}{c}37 \pm 11 \\
0 \cdot 16 \pm 0 \cdot 04 \\
327 \pm 66 \\
165 \pm 56 \\
4 \cdot 2 \pm 1 \cdot 2\end{array}$ \\
\hline
\end{tabular}

serum $\mathrm{Cu}$ concentrations. The males with moderate or severe disability and a duration of more than six years had lower serum $\mathrm{Zn}$ concentrations than the controls. Lower serum albumin levels were found in males with mild disability and in females with severe disability.

Degree of malignancy (table 6) Lower serum $\mathrm{Zn}$ concentrations were found in males with a low score (less than 9).

CSF-ANALYSIS (tables 7 and 8, fig 3)

Slightly lower CSF Zn, CSF protein and CSF albumin concentrations and $\mathrm{CSF} / \mathrm{serum}$ albumin ratio were found in the males with multiple sclerosis compared with the controls. In the females with multiple sclerosis these parameters were slightly higher than in the controls. When CSF $\mathrm{Zn}$ concentrations were related to CSF protein, CSF albumin and serum $\mathrm{Zn}$ concentrations and to CSF serum albumin ratio no correlations were found in the patients. In the controls, however, positive correlations were noted except between CSF $\mathrm{Zn}$ and serum $\mathrm{Zn}$. The best correlation was found between CSF $\mathrm{Zn}$ and CSF protein.

\section{Discussion}

The serum concentrations of $\mathrm{Zn}$ and $\mathrm{Cu}$ in the controls were within the normal range. ${ }^{28}$ The sex difference in the controls with higher serum $\mathrm{Zn}$ and lower serum $\mathrm{Cu}$ concentrations in the males also has been reported by some authors, ${ }^{152930}$ but not by others. ${ }^{31-33}$ The decreasing serum $\mathrm{Zn}$ levels with increasing age found in the control males are in accordance with the reports by Lindeman et al, ${ }^{29}$ in which this age-dependence also was found for both sexes. In another report this relationship was not found. ${ }^{34}$ The serum $\mathrm{Zn}$ concentrations are about $16 \%$ higher than the plasma $\mathrm{Zn}$ levels, mainly because zinc is released from disintegrating platelets during the clotting process. ${ }^{35}$ The increasing serum $\mathrm{Cu}$ concentrations with increasing age described by Yunice et $a l^{32}$ was not confirmed in the present study. Controls for studies on serum $\mathrm{Zn}$ and $\mathrm{Cu}$ should be matched as to age and sex.

Lower serum $\mathrm{Zn}$ concentrations were found in the patients with multiple sclerosis, which compares

Table 8 Correlation coefficients between CSF Zn and CSF protein, CSF albumin, CSF/serum albumin ratio and serum Zn in 29 patients with multiple sclerosis (MS) and controls. In both groups there are 11 males and 18 females

\begin{tabular}{lllll}
\hline & CSF Zn-CSF protein & CSF Zn-CSF alb. & CSF Zn-CSF/serum alb. & CSF Zn-serum Zn \\
\hline MS patients & $\mathrm{r}=0.27$ & $\mathrm{r}=0.31$ & $\mathrm{r}=0.27$ & $\mathrm{r}=-0.02$ \\
Controls & $\mathrm{p}=0.145$ & $\mathrm{p}=0.102$ & $\mathrm{p}=0.163$ & $\mathrm{p}=0.895$ \\
& $\mathrm{r}=0.52$ & $\mathrm{r}=0.48$ & $\mathrm{r}=0.48$ & $\mathrm{r}=-0.17$ \\
& $\mathrm{p}=0.004$. & $\mathrm{p}=0.009$ & $\mathrm{p}=0.012$ & $\mathrm{p}=0.417$ \\
\hline
\end{tabular}




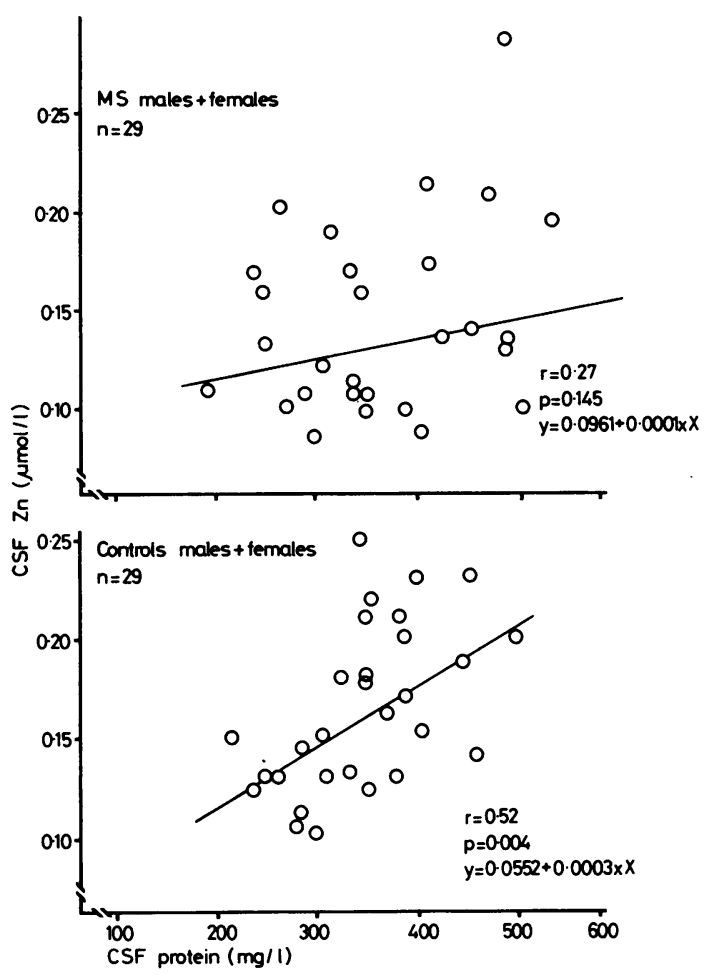

Fig 3 CSF concentrations of zinc and protein in patients with multiple sclerosis and controls $(n=29)$.

with the lower plasma $\mathrm{Zn}$ levels reported by Wong $e t$ al. ${ }^{11}$ Their study is the only one which has reported low plasma $\mathrm{Zn}$ levels in multiple sclerosis. They did not find any apparent relationship between the plasma $\mathrm{Zn}$ concentration and the clinical classification of the disease. The decreases in plasma $\mathrm{Zn}$ levels was related to age; lower plasma $\mathrm{Zn}$ levels were found under the age of 50 years. No difference in plasma $\mathrm{Zn}$ concentrations between males and females was found in the patients or controls. The depressed serum $\mathrm{Zn}$ levels noted in the present study are in contrast to the reports by Dore-Duffy $e t$ $a l,{ }^{10}$ who reported increased plasma $\mathrm{Zn}$ levels in 50 patients with multiple sclerosis.

The female patients in the present study had a less pronounced depression of the serum $\mathrm{Zn}$ level than the males. One explanation may be that most female patients and controls were in the fertile age, and variation of the serum $\mathrm{Zn}$ level is seen during the menstrual cycle. ${ }^{36}$ The lower serum $\mathrm{Zn}$ concentrations found in the younger males is in accordance with earlier reports. ${ }^{11}$

The unchanged serum $\mathrm{Cu}$ concentration in the group of patients with multiple sclerosis is in accordance with most other reports. ${ }^{13-16}$ The patients, however, had more variable concentrations than the controls, as has been reported by Plum and Hansen. ${ }^{15}$ Depressed serum Cu levels, however, were found in younger patients of both sexes in the present study.

Earlier reports of serum or plasma concentrations of $\mathrm{Zn}$ and $\mathrm{Cu}$ in multiple sclerosis have been discordant. Non-standardised blood sampling, contamination problems and the lack of age and sex matched controls may account for the differences.

A low serum $\mathrm{Zn}$ concentration may indicate a zinc deficiency or reflect a shift of $\mathrm{Zn}$ from the blood to another body pool. ${ }^{37}$ Acute or chronic infections, liver disease, neoplastic diseases, stress, corticosteroids, ACTH, oestrogens, oral contraceptives and chelating drugs such as penicillamine are known to cause low serum $\mathrm{Zn}$ levels. In these cases the serum $\mathrm{Cu}$ concentration is, as a rule, increased. In malabsorption states low serum $\mathrm{Zn}^{38}{ }^{39}$ as well as low serum $\mathrm{Cu}^{40}$ levels have been found.

In patients with multiple sclerosis evidence of malabsorption has been found by Gupta et al.$^{41}$ They described, in many of their 52 patients, abnormalities in fat excretion, the digestion of meat fibres, the excretion of d-xylose and the absorption of vitamin B12. Histological examination of the intestinal mucosa was normal in all except seven cases, who had increased inflammatory infiltration. Lange and Shiner, ${ }^{42}$ in 12 patients with multiple sclerosis, found normal jejunal biopsies in seven cases, increased inflammatory cell infiltration in three, partial villous atrophy in one and a subtotal villous atrophy in the remaining patient. Fine structural abnormalities were seen in six out of eight patients studied. Other authors ${ }^{434}$ have not found any changes of the jejunal morphology in patients with multiple sclerosis.

Malabsorption may be an explanation for the low serum $\mathrm{Zn}$ levels found in some of our patients, especially the males with slowly progressive disease, those with long duration of the disease and those with moderate or severe disability. The slightly lower serum $\mathrm{Cu}$ levels would also support a malabsorption hypothesis. The other causes of low serum $\mathrm{Zn}$ concentration for example inflammation and infection, are less probable since all patients and normal $\mathrm{Hb}$ and ESR and no fever or pressure sores were observed.

Lower serum albumin levels were found in males in remission or steady state and mild disability, and in females with severe disability. However, as a group the multiple sclerosis patients did not have low serum albumin concentrations, which have been reported by others. ${ }^{18-20}$ Unchanged serum albumin levels also were found by Dore-Duffy et al.$^{10}$ In the present study the serum concentrations of $\mathrm{Zn}$ and albumin were not found to be related, and it is not 
probable that low serum $\mathrm{Zn}$ concentrations in the patients reflect an albumin deficiency.

The CSF Zn levels measured by our method were considerably lower than in previous reports. ${ }^{23}$ Slightly lower CSF $\mathrm{Zn}$ levels were found in the males with multiple sclerosis compared to the controls. The low CSF Zn levels may refiect a zinc deficiency in the CNS. Significant correlations were found between the CSF concentrations of $\mathrm{Zn}$, protein and albumin and the CSF/serum albumin ratio in the controls. The latter ratio is considered to be a good test of the blood-brain barrier function. ${ }^{45}$ The lack of correlations in the patients with multiple sclerosis was unexpected and may indicate a changed zinc metabolism within the CNS. The importance of the low serum $\mathrm{Zn}$ concentrations in patients with multiple sclerosis is still unknown. The decrease in serum $\mathrm{Zn}$, the lack of correlation between serum $\mathrm{Zn}$ and age in the male patients, the lack of correlation between $\mathrm{CSF} \mathrm{Zn}$ and protein parameters in CSF indicate that some changes in zinc metabolism does occur in patients with multiple sclerosis.

Mickel ${ }^{46}$ has presented the following speculative hypothesis to explain the aetiology of multiple sclerosis. An enteric inflammation increases the absorption of lipid peroxides and these peroxides initiate a chain reaction propagation resulting in peroxidative attacks on poly-unsaturated fatty acids such as arachidonic acid in the platelets. Enhanced platelet aggregation occurs with release of peroxidised lipid and subsequent damage to endothelial cells and oligodendroglial cells. Zinc inhibits lipid peroxidation in vivo as well as in vitro. ${ }^{47} 48 \mathrm{It}$ is conceivable that zinc deficiency could increase the postulated peroxidative damage in multiple sclerosis. The value of zinc therapy in slowing or stopping the progress of multiple sclerosis might be worth evaluating.

The skilful technical assistance of Inger Sjöström and Ann-Marie Åhrén is gratefully acknowledged. This work was supported by grants from Amanda Wilhelmina and Per Algot Mångberg's Foundation for Medical Research, Karl Oskar Hansson's Foundation, Anders Otto Swärd's Foundation, the MS Foundation and the Faculty of Medicine, Umea University.

\section{References}

'Swank RL, Lerstad O, Ström A, Backer J. Multiple sclerosis in rural Norway. Its geographic and occupational incidence in relation to nutrition. $N$ Engl J Med 1952;246:721-8.
${ }^{2}$ National Research Council. Subcommittee on Zinc. Baltimore: University Park Press, 1979:87.

${ }^{3}$ Bennetts HW, Chapman FE. Copper deficiency in sheep in Western Australia: A preliminary account of the aetiology of enzootic ataxia of lambs and an anaemia of ewes. Aust Vet J 1937;13:138-49.

4 Miller JK, Miller WJ. Experimental zinc deficiency and recovery of calves. J Nutr 1962;76:467-74.

${ }^{5}$ Cammer W, Fredman T, Rose AL, Norton WT. Brain carbonic anhydrase: Activity in isolated myelin and the effect of hexachlorophene. $J$ Neurochem 1976;27:165-71.

- Prohaska JR, Luecke RW, Jasinski R. Effect of zinc deficiency from day 18 of gestation and/or during lactation on the development of some rat brain enzymes. $J$ Nutr 1974;104:1525-31.

${ }^{7}$ Everson GJ, Shrader RE, Wang T-I. Chemical and morphological changes in the brains of copper-deficient guinea pigs. $J$ Nutr 1968;96:115-25.

- Zimmerman AW, Matthieu J-M, Quarles RH, Brady RO, Hsu JM. Hypomyelination in copper-deficient rats. Arch Neurol 1976;33:111-9.

${ }^{9}$ Prohaska JR, Wells WW. Copper deficiency in the developing rat brain: A possible model for Menkes' steely-hair disease. $J$ Neurochem 1974;23:91-8.

${ }^{10}$ Dore-Duffy P, Catalanotto F, Ostrom M, Donaldson JO. Zinc in multiple sclerosis. Ann Neurol 1981;10:97.

" Wong Jr EK, Enomoto H, Leopold IH, et al. Plasma zinc levels in multiple sclerosis. Metab Pediatr Ophthalmol 1980;4:3-8.

${ }^{12}$ Kravtsova AF. Le taux de cuivre dans le sérum sanguin et dans le liquide céphalorachidien de malades atteints de sclérose en plaques d'appes les données de l'analyse spectrale d'émission. Zh Nevropatol Psikhiatr 1967;67:213-6.

${ }^{13}$ Wikström J, Westermarck T, Palo J. Selenium, vitamin $\mathrm{E}$ and copper in multiple sclerosis. Acta Neurol Scand 1976;54:287-90.

${ }^{14}$ Mandelbrote BM, Stanier MW, Thompson RHS, Thruston MN. Studies on copper metabolism in demyelinating diseases of the central nervous system. Brain 1948;71:212-28.

${ }^{15}$ Plum CM, Hansen SE. Studies on variation in serum copper and serum copper oxidase activity, together with studies on the copper content of the cerebrospinal fluid, with particular reference to the variations in multiple sclerosis. Acta Psychiatr Scand 1960;35 (Suppl 148):41-78.

${ }^{16}$ Bammer H. Caeruloplasmin- und Kupferstoffwechsel bei Multipler Sklerose. Dtsch Z Nervenheilk 1966;189:312-29.

${ }^{17}$ Giroux EL, Durieux M, Schechter PJ. A study of zinc distribution in human serum. Bioinorg Chem 1976;5:211-8.

18 Neumayer E, Perger F, Schinko H, Tschabitscher H. Das Serumeiweissbild bei der Multiplen Sklerose. Wiener Zeitschrift für Nervenheilkunde und deren Grenzgebiete 1956;13:46-64.

${ }^{19}$ Press EM. Electrophoresis of sera in multiple sclerosis and other neurological diseases. $J$ Neurol Neurosurg Psychiatry 1956;19:222-3. 
${ }^{20}$ Volk BW, Saifer A, Rabiner AM, Oreskes I. "Protein profile" in multiple sclerosis. AMA Arch Neurol Psych 1959;73:66-75.

${ }^{21}$ Dowling PC, Cook SD. Disease markers in acute multiple sclerosis. Arch Neurol 1976;33:668-70.

${ }^{22}$ McDonald WI, Halliday AM. Diagnosis and classification of multiple sclerosis. $\mathrm{Br} M$ Bull 1977;33:4-9.

${ }^{23}$ Palm R, Sjöström R, Hallmans G. Determination of zinc in cerebrospinal fluid. In press. Clin Chem.

${ }^{24}$ Johnson KP, Likosky WH, Nelson BJ, Fein G. Comprehensive viral immunology of multiple sclerosis. I. Clinical, epidemiological, and CSF studies. Arch Neurol 1980;37:537-41.

${ }^{25}$ Hallmans G. Absorption of topically applied zinc and changes in zinc metabolism during wound healing. An experimental and clinical investigation. Acta Derm Venereol 1978;58 (Suppl 80):9.

${ }^{26}$ Lowry OH, Rosebrough NJ, Farr AL, Randall RJ. Protein measurement with the folin phenol reagent.J Biol Chem 1951;193:265-75.

${ }^{27}$ Laurell C-B. Electroimmuno Assay. Scand J Clin Lab Invest 1972;29 (Suppl 124):21-37.

${ }^{28}$ Versieck J, Cornelis R. Normal levels of trace elements in human blood plasma or serum. Anal Chim Acta 1980;116:217-54.

${ }^{29}$ Lindeman RD, Clark ML, Colmore JP. Influence of age and sex on plasma and red-cell zinc concentrations. $J$ Gerontol 1971;26:358-63.

${ }^{30}$ Hartoma TR. Serum zinc and copper and geological environment in Finland. Ann Acad Sci Fenn Med 1977;171:1-10.

${ }^{31}$ Halsted JA, Smith JC Jr. Plasma-zinc in health and disease. Lancet $1970 ; 1: 322-4$

32 Yunice AA, Lindeman RD, Czerwinski AW, Clark M. Influence of age and sex on serum copper and ceruloplasmin levels. J. Gerontol 1974;29:277-81.

${ }^{33}$ Chooi MK, Todd JK, Boyd ND. Influence of age and sex on plasma zinc levels in normal and diabetic individuals. Nutr Metab 1976;20:135-42.

${ }^{34}$ Kiilerich S, Christensen MS, Naestoft J, Christiansen C. Determination of zinc in serum and urine by atomic absorption spectrophotometry; relationship between serum levels of zinc and proteins in 104 normal subjects. Clin Chim Acta 1980;105:231-9.
${ }^{35}$ Foley B, Johnson SA, Hackley B, Smith Jr JC, Halsted JA. Zinc content of human platelets. Proc Soc Exp Biol Med 1968;128:265-9.

${ }^{36}$ Hähn N, Paschen K, Haller J. Das Verhalten von Kupfer, Eisen, Magnesium, Calcium und Zink bei Frauen mit normalem Menstruationscyclus, unter einnahme von Ovulationshemmern und in der Gravidität. Arch Gynaekol 1972;213:176-86.

${ }^{37}$ Sandstead HH, Vo-Khactu KP, Solomons N. Conditioned zinc deficiencies. In: Prasad AS, ed. Trace Elements in Human Health and Disease. New York Academic Press, 1976; vol 1:33-49.

${ }^{38}$ Walker BE, Dawson JB, Kelleher J, Sosowsky MS. Plasma and urinary zinc in patients with malabsorption syndromes or hepatic cirrhosis. Gut 1973;14:943-8.

${ }^{39}$ Jameson S. Effects of zinc deficiency in human reproduction. Acta Med Scand 1976; Suppl 593:38-49.

${ }^{40}$ Sternlieb I, Janowitz HD. Absorption of copper in malabsorption syndromes. $J$ Clin Invest 1964;43:1049-55.

${ }^{41}$ Gupta JK, Ingegno AP, Cook AW, Pertschuk LP. Multiple sclerosis and malabsorption. Am J Gastroenterol 1977;68:560-5.

${ }^{42}$ Lange LS, Shiner M. Small-bowel abnormalities in multiple sclerosis. Lancet 1976;1:1319-22.

${ }^{43}$ Bateson MC, Hopwood D, MacGillivray JB. Jejunal morphology in multiple sclerosis. Lancet 1979;1:1108-10.

44 Jones PE, Pallis C, Peters J. Morphological and biochemical findings in jejunal biopsies from patients with multiple sclerosis. J Neurol Neurosurg Psychiatry 1979;42:402-6.

4 Tibbling G, Link H, Öhman S. Principles of albumin and IgG analyses in neurological disorders. I. Establishment of reference values. Scand J Clin Lab Invest 1977;37:385-90.

${ }^{46}$ Mickel HS. Multiple sclerosis: A new hypothesis. Perspect Biol Med 1975;18:363-74.

${ }^{47}$ Radomski MW, Wood JD. Effect of metal ions on oxygen toxicity. Aerosp Med 1970;41:1382-7.

${ }^{48}$ Chvapil M, Ryan JN, Zukoski CF. Effect of zinc on lipid peroxidation in liver microsomes and mitochondria. Proc Soc Exp. Biol Med 197.2;141:150-3. 